\title{
The Impact of the Tiananmen Crisis on China's Economic Transition
}

\section{Barry Naughton}

\section{(2) OpenEdition \\ 1 Journals}

Electronic version

URL: http://journals.openedition.org/chinaperspectives/4807

DOI: $10.4000 /$ chinaperspectives.4807

ISSN: 1996-4617

\section{Publisher}

Centre d'étude français sur la Chine contemporaine

\section{Printed version}

Date of publication: 1 June 2009

Number of pages: 63-78

ISSN: 2070-3449

\section{Electronic reference}

Barry Naughton, «The Impact of the Tiananmen Crisis on China's Economic Transition », China Perspectives [Online], 2009/2 | 2009, Online since 01 June 2011, connection on 28 October 2019. URL : http://journals.openedition.org/chinaperspectives/4807; DOI : 10.4000/chinaperspectives.4807

This text was automatically generated on 28 October 2019

(C) All rights reserved 


\title{
The Impact of the Tiananmen Crisis on China's Economic Transition
}

\author{
Barry Naughton
}

\section{ABSTRACTS}

The social and economic model that emerged out of the Tiananmen crisis was profoundly different from that contemplated on the eve of Tiananmen. China made a firm transition to a high-input, high investment, high growth model of development. The broad but vague social consensus in favour of political and economic reforms that underlay the Tiananmen protests crumbled, while the economy boomed and some people became much better off. In the postTiananmen period a strong economic logic and a strong political logic coincided to produce a policy regime that was remarkably consistent and strongly self-replicating.

\section{AUTHOR}

\section{BARRY NAUGHTON}

So Kwanlok Chair of Chinese International Affairs at the Graduate School of International Relations and Pacific Studies at the University of California, San Diego. 